\title{
Cold Induced Rhabdomyolysis in Carnitine Palmyityl Transferase Deficiency
}

\author{
A. K. W.BROWNELL, D.L.SEVERSON, C. D.THOMPSON, and T.FLETCHER
}

SUMMARY: A case of carnitine palmityl transferase deficiency in skeletal muscle is described. The usual symptoms associated with this disease (recurrent muscle cramps or pain and pigmenturia) were not $o b$ served but sudden exposure to cold precipitate rhabdomyolysis in this patient.

RÉSUMÉ: Rhabdomyolyse au froid chez un patient avec déficience de la carnitine palmityl transferase musculaire.

Nous décrivons un cas de déficience de la carnitine palmityl transferase musculaire. Les symptômes généralement trouvés dans cette maladie (crampes musculaires récurrentes, douleurs, pigmenturie) ne furent pas observés, mais l'exposition soudaine au froid précipitait une rhabdomyolyse chez ce patient.
From the Divisions of Medicine, Pathology, and Pharmacology, Faculty of Medicine. The University of Calgary, Calgary, Alberta.

Reprint requests to: Dr. A. K. W. Brownell, University of Calgary. Faculty of Medicine, 2920-24 Ave. N.W., Calgary T2N 1N4, Canada

\section{INTRODUCTION}

Carnitine palmityl transferase (CPT) deficiency in skeletal muscle was first reported in 1973 as a cause of rhabdomyolysis. (DiMauro et al., 1973). To date, a total of twelve cases have been reported (DiMauro et al., 1973; Bank et al., 1975; Cummings et al., 1976; Herman et al., 1977; Carrol et al., 1978; Hostetler et al., 1978; Patten et al., 1978; Reza et al., 1978; DiDonato et al., 1978). The clinical picture is variable. Most patients present with recurrent attacks of muscle cramps or pain and pigmenturia over many years (DiMauro et al., 1973; Cummings et al., 1976; Hostetler et al., 1978; Patten et al., 1978; Reza et al., 1978), while two patients have had only rare attacks (Banks et al., 1975; Reza et al., 1978). When precipitating factors can be recognized it is usually the performance of unusually vigorous muscular activity or muscular activity associated with fasting or missed meals. (Reza et al., 1978; Banks et al., 1975). We report another case in which sudden exposure to cold appeared to be the triggering agent for the acute rhabdomyolysis.

\section{CASE PRESENTATION}

A 23-year-old man hiked for four hours on an easy mountain trail. His dietary intake and pattern of sleep were normal in the few days preceding the hike. He slipped and fell into a cold mountain lake. Only the lower half of his body was immersed in the water. $\mathrm{He}$ climbed out of the water immediately and within minutes felt lightheaded and developed cramping pain in his feet which spread proximally within 30 minutes to involve his legs, thighs and buttocks. In the ensuing six hours he developed pigmenturia and marked leg weakness. During the next five days progressive renal failure developed.

The patient recalled a similar, but less severe, two day episode at age 20 . On that occasion the symptoms developed following participating in a hockey game. He had always been active in athletics, hiked regularly, could run up to five miles at a time, and was attending university supported by a hockey scholarship. The family history was normal.

Physical examination five days following the onset of symptoms demonstrated heavy muscle bulk, no muscle tenderness to palpation, and moderate weakness of pelvic girdle muscles, hamstrings, and ankle dorsiflexors.

The results of laboratory studies were as follows: blood urea nitrogen $83 \mathrm{mg} / \mathrm{dl}$ (normal 10-20 mg/dl); creatinine $9.1 \mathrm{mg} / \mathrm{dl}$ (normal $0.7-1.4$ $\mathrm{mg} / \mathrm{dl}$ ); uric acid $13.2 \mathrm{mg} / \mathrm{dl}$ (normal 3.9-9 $\mathrm{mg} / \mathrm{dl}$ ); creatine kinase more than $4800 \mathrm{IU} / \mathrm{L}$ (Normal 100-225 $\mathrm{IU} / \mathrm{L}$ ); hemaglobin $14.1 \mathrm{gms} \%$ (normal 14-18 gms\%) and white blood cell count of $7300 / \mathrm{mm}^{3}$ (normal 4000 $11000 / \mathrm{mm}^{3}$ ). The urine showed a strongly positive orthotilidine reaction but only a few red blood cells were seen microscopically.

A diagnosis of renal failure secondary to massive rhabdomyolysis was made. With medical management his renal function returned to normal.

Further laboratory tests after recovery of his renal function indicated a fasting serum cholesterol of $181 \mathrm{mg} / \mathrm{dl}$ (normal $140-270 \mathrm{mg} / \mathrm{dl}$ ) and triglycerides of $187 \mathrm{mg} / \mathrm{dl}$ (normal $30-150 \mathrm{mg} / \mathrm{dl}$ ). The lipoprotein electrophoresis showed a slight elevation of the pre-beta fraction. 
Electromyography showed a moderate number of low amplitude, short duration motor units in muscles of the lower extremities. An ischemic exercise test showed a ten fold rise above baseline of venous lactate levels. A muscle biopsy was taken from the right vastus lateralis.

\section{METHODS}

The muscle was processed for light and electron microscopy (Engel et al., 1968). Fresh frozen sections of muscle were stained by hematoxylin and eosin, modified Gomori trichrome, and oil red 0 . The following histochemical reactions were performed: adenosine triphosphatase, nicotinamide adenine dinucleotide dehydrogenase, phosphorylase, acid

The muscle used for the CPT assay was frozen immediately in isopentane chilled in liquid nitrogen, transported to the laboratory in liquid nitrogen and stored at $-80^{\circ} \mathrm{C}$. A $10 \%$ homogenate of skeletal muscle was prepared in Chappel Perry solution (100 m M KCl, $50 \mathrm{mM}$ Tris, $5 \mathrm{mM} \mathrm{Mg}$ $\mathrm{SO}_{4} \quad 7 \mathrm{H}_{2} \mathrm{O}$, and $1 \mathrm{mM} \mathrm{Na}$ EDTA adjusted to $\mathrm{pH}$ 7.2) by homogenization for three fifteen second intervals in a Polytron PT-10 tissue disintegrator. CPT activity was determined by the isotope exchange method phosphatase, and Periodic acid Shiff.

(Norum, 1964). All assays were performed in duplicate with incubation times of fifteen and thirty minutes. The protein content of the homogenate was determined by the method of Lowry (1951). Enzyme activity, calculated as nanomoles of palmityl carnitine formed per minute per milligram of protein, was averaged from the two incubation times.

\section{RESULTS}

1. Muscle morphology - the cross sectional diameter of Type I and Type II fibers are listed in Table 1. Occasional necrotic fibers invaded by macrophages were observed. In trichromatically stained sections, numerous clear spaces under $1 \mu$ in diameter were seen in some fibers. (Figure 1). These clear spaces reacted positively for oil red 0 and occurred only in Type I fibers. Increased oxidative enzyme activity was seen surrounding these clear spaces. Electron microscopic examination of fibers showed no abnormality except for a mild increase in the lipid droplet content of some fibers.

2. Muscle biochemistry - Table 2 lists the CPT activity from 15 control muscles as well as the patient's muscle. The patient's muscle contained $20.5 \%$ of the mean activity present in control muscle.

TABLE 1

Size Characteristics of Muscle Fibers

\begin{tabular}{|c|c|c|}
\hline $\begin{array}{l}\text { MUSCLE } \\
\text { FIBER } \\
\text { TYPE }\end{array}$ & $\begin{array}{l}\text { MEAN DIAMETER I STANDARD } \\
\text { ERROR (MICRONS) } \\
\text { OF MUSCLE FIBERS }\end{array}$ & $\begin{array}{l}\text { RANGE OF DIAMETERS } \\
\text { (MICRONS) OF } \\
\text { MUSCLE FIBERS }\end{array}$ \\
\hline I & $51.5 \pm 11.65$ & $20-75$ \\
\hline II & $61.38 \pm 14.45$ & $16-105$ \\
\hline
\end{tabular}

TABLE 2

CPT Activity in Human Muscle* (Method of NORUM 1964)

$\begin{array}{ll}\text { CONTROLS } & 0.73 \pm 0.11(\mathrm{n}=15)^{\Delta} \\ \text { PATIENT } & 0.15 \text { or } 20.54 \%\end{array}$

* ACTIVITY EXPRESSED AS NMOLES OF PALMITYL CARNITINE FORMED/MIN/MG OF PROTEIN \pm S.E.

$\triangle$ CONTROLS CONSIST OF 10 PATIENTS WITHOUT -MUSCLE DISEASE AND 5 PATIENTS WITH MUSCLE DISEASE (2 LIMB GIR DLE DYSTROPHY, I MYOTONIC DYSTROPHY, 1 INFLAMMATORY MYOPATHY, 1 TYPE II ATROPHY).

\section{DISCUSSION}

Before long chain fatty acids (LCFA) can be metabolized within muscle fibers, they must gain access to the inner part of the mitochondrion. LCFA do not readily permeate mitochondrial membranes but their carnitine esters do. The following sequence of reactions occur. First, LCFA are activated to co-enzyme esters; second, the reversible transfer of LCFA from fatty acyl co-enzyme A to carnitine occurs. This reaction is catalyzed by CPT which occurs in two forms. Type 1 CPT is bound to the outer face of the inner mitrochondrial membrane and catalyses the formation of palmityl carnitine. Type 2 CPT is located on the inside of the same membrane and catalyses the reverse reaction leading to the formation of LCF acyl co-enzyme A. (Banks et al., 1975). The LCFA can now undergo beta oxidation with ultimate production of ATP. Figure 2 is a summary of these reactions.

Our studies do not allow us to conclude if one or the other of the CPT's were selectively affected. DiMauro et al (1973) concluded that their patient had primarily a CPT 1 abnormality while Patten et al (1978) concluded that their patient had a deficiency of CPT 2.

No explanation has been advanced to explain the varied clinical symptoms in spite of the same biochemical defect. Could the differences be explained on the basis of the amount of residual enzyme activity in different cases? Our patient had $20.5 \%$ of normal CPT activity in the biopsied skeletal muscle and he had had only two clinical attacks. Using the same assay, DiMauro et al (1973) patient had $23 \%$ of normal CPT activity in his muscle, yet he suffered numerous attacks. Another patient reported by Hostetler et al (1978) with $46 \%$ of control CPT activity had three to four attacks per year for seven years. Therefore, the clinical variation cannot be explained by referring to the actual levels of total CPT within muscles.

Our patient demonstrated a clear cut relationship between sudden exposure to cold and the production of rhabdomyolysis. The mechanism 


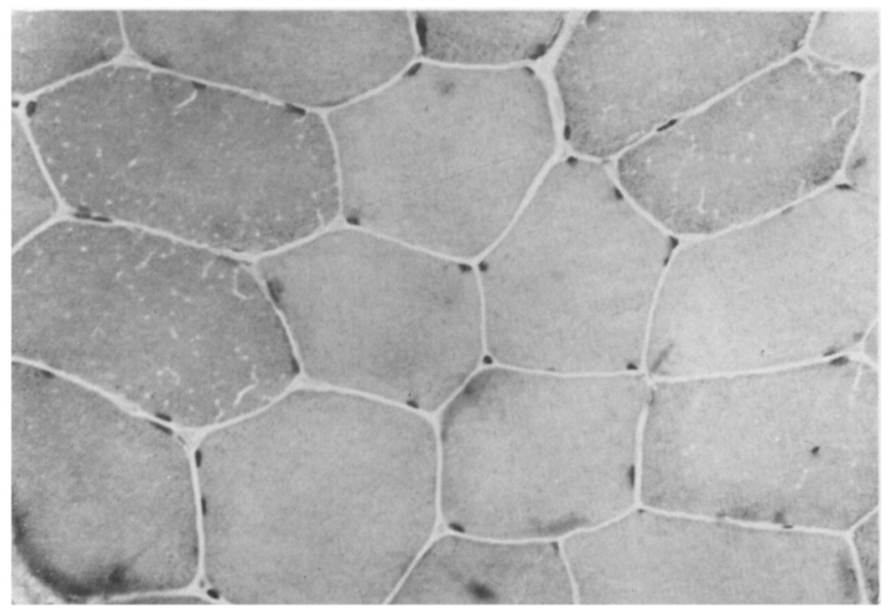

Figure 1 - Fresh frozen section of muscle stained by the modified trichrome reaction. Multiple clear spaces are noted in some fibers (X 375).

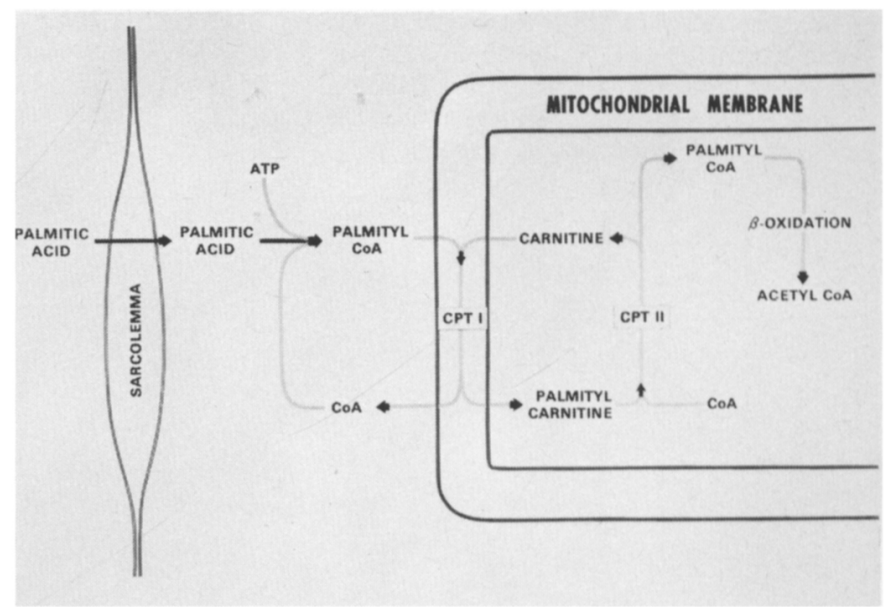

Figure 2 - Outline of the steps involved in long chain fatty acid metabolism. whereby cold could lead to rhabdomyolysis is uncertain, but at least two hypotheses can be advanced to explain the clinical observation.

First, with sudden immersion of the lower half of the body in cold water there would be a tendency for the body temperature to drop. To maintain a normal central body temperature extra heat would have to be generated. The most important mechanisms for producing extra heat in most adult mammals is shivering in voluntary skeletal muscles. (Thompson et al., 1977). Shivering is produced by active muscle contraction. We could then expect the patient to begin shivering on exposure to the cold and thus the amount of muscular work would have to increase further. If as a result of the deficiency of CPT the muscles had been metabolizing LCFA maximally prior to the immersion in cold water, they would not be able to further increase their LCFA metabolism to produce the extra ATP for muscle contraction to occur to produce the shivering. Thus an energy deficit would occur. This deficit of energy could lead to rhabdomyolysis as acute muscle necrosis seems to be related to failure of energy production and possible depletion of ATP necessary to maintain the integrity of the sarcolemma (Rowland et al., 1972).

A second hypothesis concerns the effect of cold on ketone body production. Cold is reported to produce a physiologic ketosis (Johnson et al., 1961). Ketones may be quantitatively important energy supplying substrates for skeletal muscle (Reza et al., 1978). Three patients with this syndrome have been shown to have defective ketone body formation (Banks et al., 1975; Carrol et al., 1978 and Reza et al., 1978). If our patient had this defect, then, on partial immersion in cold water, he might not have been able to produce the normal amount of ketone bodies which could aggravate the energy crisis in his muscle and lead to rhabdomyolysis. Unfortunately, no assessment of ketone body production was carried out in this patient.

\section{REFERENCES}

BANKS, W. J., DIMAURO, S., BONILlA, E., CAPUZZI, D.M. and ROWLAND, L. P. (1975). A disorder of Muscle Lipid Metabolism and Myoglobinuria. The New England Journal of Medicine, 292:9, 443449.

CAR ROLL, J. E., BROOKE, M. H., DEVIVO, D. C., KAISER, K. K. and HAGBERG, J. H. (1978). Biochemical and Physiologic Consequences of Carnitine Palmityl Transferase Deficiency. Muscle and Nerve, 1:2, 103-110.

CUMMING, W. J. K., HARDY, M., HUDGSON, P. and WALLS, J. (1976). Carnitine Palmityl Transferase Deficiency. Journal of the Neurological Sciences, 30: 247-258.
DICONATO, S., CORNELIO, F., PACINI, L., PELUCHETTI, D., RIMOLDI, M. and SPREAFICO, S. (1978). Muscle Carnitine Palmityl Deficiency: A Case with Enzyme Deficiency in Cultured Fibroblasts. Annals of Neurology, 4:5, 465-467.

DIMAURO, $S$. and MELIS DIMAURO, P., (1973). Muscle Carnitine Palmityltransferase Deficiency and Myoglobinuria. Science, $182,929-931$

ENGLE, A. G. and DALE, A. J. D. (1968). Autophagic Glycogenosis of Late Onset with Mitochondrial Abnormalities. Mayo Clinic Proceedings, 43, 233-279.

HERMAN, J. and NADLER, H. L. (1977). Recurrent Myoglobinuria and Muscle Carnitine Palmityl Transferase Deficiency. The Journal of Pediatrics, 91:2, 247-250.

HOSTETLER, K. Y., HOPPEL, C. L., ROMINE, J. S., SIPE, J. C., GROSS, S. R. and HIGGINBOTTOM, P. A. (1978). Partial Deficiency of Muscle Carnitine Palmityl Transferase with Normal Ketone Production. The New England Journal of Medicine, 298:10, 553-557.

JOHNSON, R. E., PASSMORE, R. and SARGENT, F, (1961). Multiple Factors in Experimental Ketosis. Archives of Internal Medicine, 107, 111-118.

LOWRY, O. H., ROSENBROUGH, N. J., FARR, A. L. and RANDALL, R. J. (1951). Protein Measurement with the Folin Phenol Reagent. Journal of Biological Chemistry, 193, 265-275.

NORUM. K. R. (1964). Palmityl-CoA: Carnitine Palmityltransferase. Biochemica et Biophysica Acta, 89, 95-108.

PATTEN, B. M., WOOD, J., HOWELL, R. R., HEFERAN, P. and DIMAURO, S. (1978). Carnitine Palmityl Transferase Deficiency in Two Brothers with Recurrent Rhabdomyolysis, Neurology, 4:28, 399. 
- REZA, M. J., KAR, N. C., PEARSON, C. M. and KARK, P. (1978). Recurrent Myoglobinuria due to Muscle Carnitine Palmityl Transferase Deficiency. Annals of Internal Medicine, 88: 610-615.
ROWLAND, L. P. and PENN, A. S. (1972).

Myoglobinuria: Medical Clinics of North

America, 56, 1233-1256.
THOMPSON, G. E. (1977). Physiologica! Effects of Cold Exposure. In Robertshaw, D. (Editor); International Review of Physiology, Environmental Physiology II, Volume 15, University Park Press, Baltimore, 45 